\title{
Pengaruh Laju Penginjeksian Doping Fluor terhadap Aktivitas Fotokatalis Nanotitania Menggunakan Metode Sol Gel
}

\author{
Sri Rahayu ${ }^{(1 \mathrm{a})^{*}}$, Posman Manurung $^{(\mathrm{b})}$, Ronyus Marjunus $^{(\mathrm{c})}$ \\ Jurusan Fisika, Universitas Lampung, Bandar Lampung, Indonesia, 35141 \\ Email::(a*) srirahayu100355@gmail.com, ${ }^{(b)}$ posman65@unila.ac.id, ${ }^{(c)}$ roniyus@unila.ac.id
}

Diterima (23 September 2019), Direvisi (25 April 2020)

\begin{abstract}
The titania synthesis of fluorine doping $\left(\mathrm{F}^{\left.-\mathrm{TiO}_{2}\right)}\right.$ was carried out through the sol-gel method. Titanium isopropoxide (TTIP), tween-80, isopropanol and ammonium fluoride (NH4F) as sources of doping fluorine were used as the main ingredients. This research aimed to study the effect of fluorine doping injection rate using injection pumps on $\mathrm{F}-\mathrm{TiO}_{2}$ photocatalyst activity. Four fluorine doping samples were prepared with the respective penetration rate of $0.4 \mathrm{ml} / 30$ minutes; $0.4 \mathrm{ml} / 60$ minutes; $0.4 \mathrm{ml} / 90$ minutes and $0.4 \mathrm{ml} /$ 120 minutes. The titania powder was calcined at $450{ }^{\circ} \mathrm{C}$ for 5 hours. The sintered sample was tested for photodegradation of remazol yellow under UV light. Physical characteristics were analyzed using transmission electron microscopy (TEM) and Uv-Vis spectrophotometer. The results of the UV-Vis spectrophotometer showed that the particle size of samples with an injection rate of $0.4 \mathrm{ml} / 90$ minutes showed higher photocatalyst activity with particle sizes of $(14 \mathrm{~nm} \pm 4 \mathrm{~nm})$.
\end{abstract}

Keywords: fluor doped, photodegradation, remazol yellow, titania

Abstrak. Sintesis titania doping fluor $\left(\mathrm{F}-\mathrm{TiO}_{2}\right)$ dilakukan melalui metode sol-gel. Titanium isopropoksida (TTIP), tween-80, isopropanol dan ammonium fluorida $\left(\mathrm{NH}_{4} \mathrm{~F}\right)$ sebagai sumber doping fluor digunakan sebagai bahan utama. Penelitian ini bertujuan untuk mempelajari pengaruh laju penginjeksian doping fluor menggunakan pompa injeksi terhadap aktivitas fotokatalis $\mathrm{F}_{-} \mathrm{TiO}_{2}$. Empat sampel doping fluor dipreparasi dengan laju penetesa masing-masing $0,4 \mathrm{ml} / 30$ menit; $0,4 \mathrm{ml} / 60$ menit; $0,4 \mathrm{ml} / 90$ menit dan $0,4 \mathrm{ml} / 120$ menit. Serbuk titania dikalsinasi pada suhu $450{ }^{\circ} \mathrm{C}$ selama $5 \mathrm{jam}$. Sampel yang disinter diuji untuk fotodegradasi remazol kuning di bawah sinar UV. Karakteristik fisika dianallisis menggunakan transmission electron microscopy (TEM) dan Spektrofotometer Uv-Vis. Hasil pengujian spektrofotometer UV-Vis menunjukkan bahwa ukuran partikel sampel dengan laju penginjeksian 0,4 ml/90 menit menunjukkan aktivitas fotokatalis yang lebih tinggi dengan ukuran partikel sebesar $(14 \mathrm{~nm} \pm 4 \mathrm{~nm})$.

Kata kunci: doping fluor, fotodegrasi, remazol kuning, titania

\section{PENDAHULUAN}

Nanoteknologi adalah teknologi pada struktur yang sangat kecil dengan kisaran ukuran 0,1 sampai $100 \mathrm{~nm}$. Berdasarkan penelitian sebelumnya sifat-sifat nano berbeda, antara lain sensitivitas suhu tinggi, luas permukaan besar, ketahanan regangan tinggi dan listrik rendah [1]. Selain itu nanoteknologi juga memiliki peran yang sangat penting dalam bidang nanokimia, nanofisika, nanomaterial, nanoelektronik, nanobionik dan nanometrologi [2].

Nanomaterial memiliki berbagai jenis, salah satunya yaitu titanium dioksida $\left(\mathrm{TiO}_{2}\right)$ atau nanotitania merupakan salah satu bahan 
yang sedang dikembangkan. $\mathrm{TiO}_{2}$ lebih unggul dibandingkan dengan semikonduktor yang lain dikarenakan lebih murah [3], tidak beracun [4]. Untuk nanopartikel $\mathrm{TiO}_{2}$ aktivitas katalitik meningkat pada ukuran partikel di bawah $20 \mathrm{~nm}$. $\mathrm{TiO}_{2}$ memiliki tiga fase yaitu: anatase (tetragonal, celah pita 3,3 $\mathrm{eV}$ ), rutile (tetragonal, celah pita $3,1 \mathrm{eV}$ ) dan brookite (ortorombik). Pada proses fotokatalisis fasa rutil maupun anatase dapat digunakan namun dalam aplikasinya anatase memiliki potensi yang paling besar untuk digunakan sebagai fotokatalis [5].

Sebagai fotokatalis, $\mathrm{TiO}_{2}$ memiliki keunggulan antara lain memiliki potensial tinggi, harganya murah dan kestabilannya tinggi apabila dikenai cahaya [6] . Namun, celah pita energi dengan lebar $(\sim 3,2 \mathrm{eV})$ menyebabkan efisiensi fotokatalis terbatas hanya sebesar 5\% [7], sehingga $\mathrm{TiO}_{2}$ murni hanya mampu menggunakan sekitar $4 \%$ dari spektrum matahari [8]. Untuk memanfaatkan nanotitania sebaik mungkin, dapat dilakukan berbagai metode untuk mengecilkan celah pita, salah satunya adalah doping.

Doping merupakan suatu proses yang digunakan untuk memodifikasi konduktivitas suatu bahan. Terdapat berbagai macam bahan doping dalam nanoteknologi dan semikonduktor antara lain nitrogen [9], karbon [10] , sulfur [11] dan fluor [12].

Selain itu, sintesis nanotitania dapat dilakukan dengan berbagai metode, diantaranya presipitasi, sol gel, penambahan lambat dari prekursor titanium alkoksida [13], dan hidrotermal [14]. Metode-metode tersebut memiliki kelebihan dan kekurangan sehingga dapat mempengaruhi morfologi, struktur kristal, stabilitas fasa dari bahan yang digunakan dalam sintesis nanotitania [15] . Metode yang sering digunakan dalam sintesis nanotitania adalah metode sol gel. Metode sol-gel merupakan metode sintesis dengan langkah yang sederhana, tidak memerlukan peralatan khusus dan tidak menghasilkan produk beracun [16].

Penambahan doping fluor (F) dengan menggunakan metode sol gel dipandang dapat meningkatkan kristalinitas nanotitania. Hasil uji transmission electron microscopy (TEM) dengan menggunakan doping fluor didapatkan ukuran partikel nanotitania 22,6 nm dan 21,1 nm [17].

Penelitian yang dilakukan $\mathrm{Yu}$ et al. (2002) telah membuktikan bahwa penambahan fluor pada $\mathrm{TiO}_{2}$ dapat meningkatkan aktivitas fotokatalis dan menurunkan ukuran partikel $\mathrm{TiO}_{2}$ [18]. Sehingga pada penelitian ini dilakukan modifikasi $\mathrm{TiO}_{2}$ doping fluor dengan variasi laju penginjeksian doping fluor dari $\mathrm{NH}_{4} \mathrm{~F}$ menggunakan pompa injeksi untuk melihat pengaruh laju injeksi doping fluor terhadap aktivitas fotokatalis $\mathrm{TiO}_{2}$ menggunakan metode sol-gel.

\section{METODE PENELITIAN}

Alat yang digunakan pada penelitan ini adalah gelas sampel, mikro pipet, pengaduk magnetik, neraca digital, mortar akik, oven, furnace, lampu UV Ultra Vitalux 230 E27 Osram dan pompa injeksi XB-500. Sedangkan bahan yang digunakan adalah titanium (IV) isopropoksida $\left[\mathrm{Ti}\left(\mathrm{OC}_{3} \mathrm{H}_{7}\right)_{4}\right]$ dengan kemurnian 97\% dari Sigma-Aldrich, 2-propanol pro analisis (isopropanol) $98 \%$ Merck, amonium fluorida $\left(\mathrm{NH}_{4} \mathrm{~F}\right) \mathrm{98 \%}$, tween-80 $\left(\mathrm{C}_{64} \mathrm{H}_{124} \mathrm{O}_{26}\right)$ Merck, remazol kuning dan aquades.

Sintesis $\mathrm{F}_{-}-\mathrm{TiO}_{2}$ dilakukan melalui pencampuran titanium isopropoksida, isopropanol, tween-80 dan $\mathrm{NH}_{4} \mathrm{~F}$. Dalam hal ini, isopropanol sebagi pelarut dan $\mathrm{NH}_{4} \mathrm{~F}$ sebagai sumber doping fluor. Komposisi pada masing-masing sampel ditunjukkan pada Tabel 1. 
Tabel 1. Variasi laju injeksi doping fluor pada setiap sampel

\begin{tabular}{cccccc}
\hline Sampel & $\begin{array}{c}\text { Tween-80 } \\
(\text { gram })\end{array}$ & $\begin{array}{c}\text { i-PrOH } \\
(\mathrm{ml})\end{array}$ & TTIP $(\mathrm{ml})$ & $\begin{array}{c}\mathrm{NH}_{4} \mathrm{~F} 1 \mathrm{M} \\
(\mathrm{ml})\end{array}$ & $\begin{array}{c}\text { Laju injeksi doping } \\
(\text { menit })\end{array}$ \\
\hline F-01 & 20 & 80 & 8 & 0,4 & - \\
F-02 & 20 & 80 & 8 & 0,4 & 30 \\
F-03 & 20 & 80 & 8 & 0,4 & 60 \\
F-04 & 20 & 80 & 8 & 0,4 & 90 \\
F-05 & 20 & 80 & 8 & 0,4 & 120 \\
\hline
\end{tabular}

Proses sintesis dimulai dengan menimbang 20 gram tween-80 menggunakan neraca digital. Kemudian menambahkan $80 \mathrm{ml}$ isopropanol dan diaduk selama 20 menit. Setelah itu menambahkan titanium isopropoksida sebanyak $8 \mathrm{ml} \mathrm{ke}$ dalam larutan dan dilanjutkan pengadukan selama 30 menit. Kemudian menambahkan $\mathrm{NH}_{4} \mathrm{~F}$ sebanyak $0,4 \mathrm{ml}$ dengan variasi laju penginjeksian pada masing-masing sampel $0,4 \mathrm{ml} / 0$ menit; $0,4 \mathrm{ml} / 30$ menit; $0,4 \mathrm{ml} / 60$ menit; $0,4 \mathrm{ml} / 90$ menit dan $0,4 \mathrm{ml} / 120$ menit. Lalu dilanjutkan pengadukan selama 24 jam utuk mencapai homogenitas.

Larutan kemudian dikeringkan dalam oven pada suhu $80{ }^{\circ} \mathrm{C}$ selama 72 jam untuk menghilangkan kadar uap air. Setelah itu dilakukan kalsinasi pada suhu $450{ }^{\circ} \mathrm{C}$ selama 5 jam untuk menghilangkan zat-zat yang tidak diperlukan. Serbuk yang terbentuk kemudian digerus menggunakan mortar akik dan diuji spektrofotometer UV-Vis untuk mengetahui aktivitas fotokatalis serta karakterisasi menggunakan TEM untuk melihat ukuran partikel $\mathrm{F}-\mathrm{TiO}_{2}$.

Pengujian fotokatalis dilakukan pada larutan remazol kuning $10 \mathrm{ppm}$ dari $3 \mathrm{ml}$ remazol kuning, $297 \mathrm{ml}$ aquabides dan 0,25 gram $\mathrm{TiO}_{2}$ doping sulfur. Ketiga bahan tersebut dicampur dan diaduk hingga larutan homogen. Kemudian dilakukan penyinaran dibawah lampu Osram Ultra Vitalux 300 Watt. Selanjutnya, dilakukan pengambilan larutan sebanyak $20 \mathrm{ml}$ setiap 10 menit sebanyak 5 kali. Larutan yang telah disinari kemudian diuji spektrofotometer UV-Vis menggunakan Cary 100 versi 12.00 untuk memperoleh data absorbansi pada panjang gelombang tertentu.

Untuk proses karakterisasi TEM diawali dengan mencampurkan sampel dengan dispersan. Terdapat tiga dispersan yang umumnya digunakan antara lain aquabides, etanol dan aseton yang disesuaikan dengan identitas sampel. Selanjutnya, sampel diletakkan pada grid atau substrat yang diketahui memiliki lubang-lubang tak kasat mata. Kemudian sampel siap untuk dikarakterisasi dengan alat TEM. Mulamula sampel dimasukkan ke dalam alat TEM yang telah divakumkan sebelumnya. Kemudian dilakukan pengaturan tegangan sehingga elektron mampu menembus daerah terang atau lubang-lubang tak kasat mata pada grid. Kemampuan elektron tersebut yang selanjutnya digunakan untuk menunjukkan daerah sampel. Setelah itu, dilakukan penentuan fokus dan daerah yang akan dilakukan pengujian sehingga diperoleh hasil foto dengan skala pengukuran tertentu. Hasil foto tersebut dapat diolah untuk menentukan distribusi ukuran partikel menggunakan program ImageJ. 


\section{HASIL DAN PEMBAHASAN}

Gambar 1 merupakan hasil pengujian fotokatalis $\mathrm{F}-\mathrm{TiO}_{2}$.

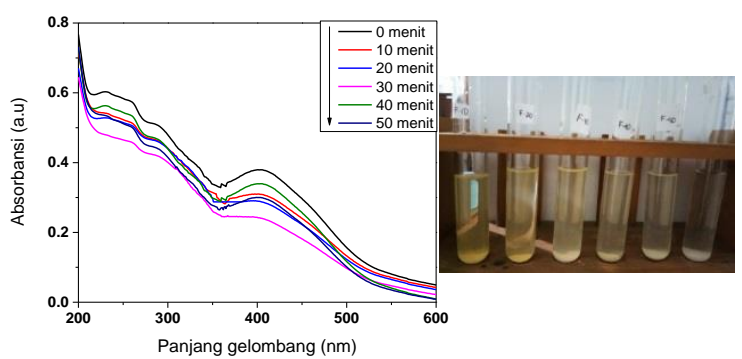

(a)

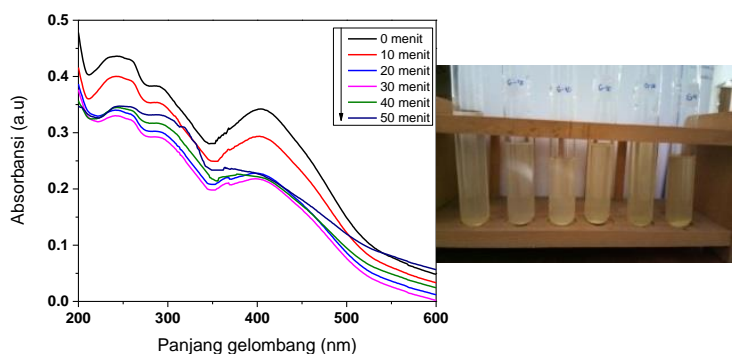

(c)

(d)

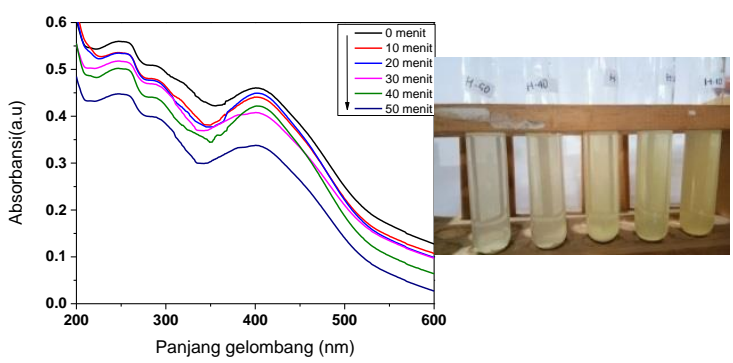

(e)

Gambar 1. Hasil uji fotokatalis pendegradasian remazol kuning dibawah lampu UV (a) grafik F-01 (b) degradasi F-01 (c) grafik F-02 (d) degradasi F-02 (e) grafik F-03 dan (f) degradasi F-03

Gambar 1 menunjukkan hasil uji fotokatalis dari sampel F-01, F-02 dan F-03. Tampak bahwa degradasi perubahan warna yang dihasilkan untuk F-01, F-02, dan F-03 tidak terlihat secara signifikan dimana warna cenderung tetap seperti Gambar 1.b., Gambar 1.d, dan Gambar 1.f. Oleh karena itu, untuk mengetahui panjang gelombang maksimum dan degradasi larutan remazol kuning keemasan maka dilakukan uji spektrofotometer UV-Vis. Pada Gambar 1.a. menunjukkan adanya penurunan yang sangat kecil namun pada 40 menit pendegradasian mengalami kenaikan kembali. Hal tersebut mengakibatkan aktivitas fotokatalis sampel ini rendah dikarenakan menurut penelitian Sari, pendegradasian mengalami penurunan setiap 10 menit[17].Sedangkan pada Gambar 1.c. diperoleh adanya penurunan, hal tersebut dikarenakan adanya pengaruh laju penginjeksian doping $\mathrm{NH}_{4} \mathrm{~F}$ selama 30 menit. Pada Gambar 1.e. menunjukkan adanya penurunan yang lebih baik dibandingkan sampel F-03. Hal tersebut menunjukkan aktivitas fotokatalis sampel ini mulai meningkat dengan pengaruh laju injeksi doping $\mathrm{NH}_{4} \mathrm{~F}$ terhadap pendegradasian larutan remazol kuning di bawah lampu UV selama 50 menit dengan pengambilan setiap 10 menit.

Degradasi larutan remazol kuning dapat diketahui melalui uji spektrofotometer UVVis. Hasil pengujian spektrofotometer UVVis sampel F-04 dan F-05 ditunjukkan pada Gambar 2. 


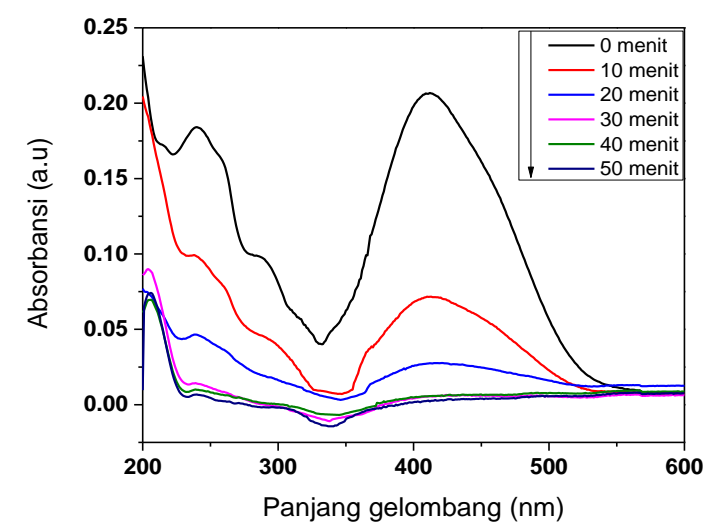

(a)

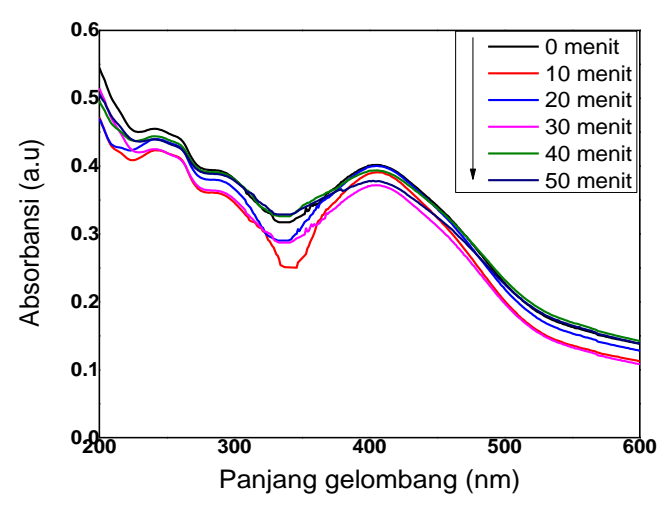

(c)

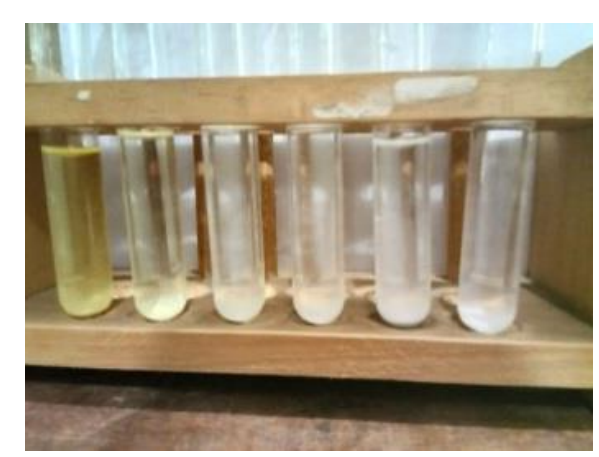

(b)

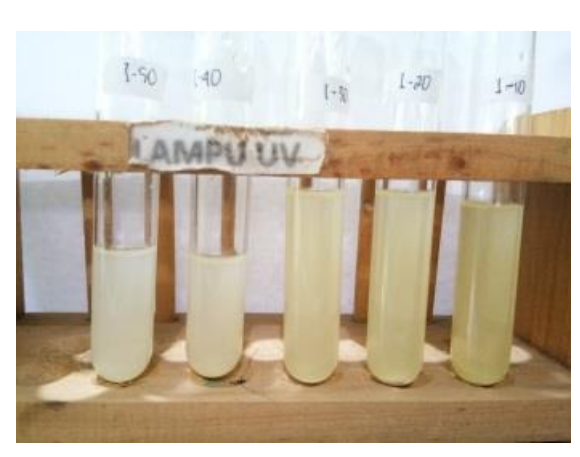

(d)

Gambar 2. Hasil pengulasan spektrofotometri Uv-Vis menggunakan lampu UV (a) grafik F-04 (b) degradasi F-04 (c) grafik F-05 (d) degradasi F-05

\begin{abstract}
Berdasarkan hasil pengulasan spektrofotometer UV-Vis yang diperlihatkan Gambar 2.b. tampak terjadi perubahan warna yaitu berubah menjadi putih ini menunjukkan adanya penurunan absorbansi yang berarti aktivitas fotokatalis meningkat. Pada Gambar 2.a.tampak bahwa penyinaran 10 menit terlihat persentase penurunan absorbansi hingga \pm 0.13 terhadap sampel 0 menit. Sedangkan pada penyinaran 50 menit dihasilkan nilai absorbansi nol. Hal tersebut menunjukkan bahwa remazol kuning keemasan sudah terurai dan hanya tersisa titania.
\end{abstract}

Dimana warna larutan sebelum dilakukan penyinaran adalah kuning terang dan seiring dengan lamanya waktu penyinaran, warna larutan berubah menjadi putih bening. Perubahan warna terjadi akibat degradasi zat warna oleh $\mathrm{TiO}_{2}$ sebagai fotokatalis yang merupakan bahan semikonduktor.

Proses fotokatalis diawali karena adanya eksitasi elektron dari pita valensi ke pita konduksi pada material semikonduktor ketika dikenai energi dari lampu UV. Ketika semikonduktor $\mathrm{TiO}_{2}$ yang memiliki pita valensi penuh dan pita konduksi kosong disinari panjang gelombang tertentu yang memiliki energi lebih besar dibandingkan celah pita energinya maka elektron $\left(\mathrm{e}^{-}\right)$yang 
terdapat pada pita valensi akan tereksitasi menuju pita konduksi sehingga meninggalkan lubang $\left(\mathrm{h}^{+}\right)$pada pita valensi. Kondisi ini memungkinkan interaksi antara pasangan elektron dan lubang dengan zat kimia lain pada permukaan. Kemampuan ini yang dimanfaatkan untuk menyerap senyawa organik seperti zat warna dalam larutan [19].

Pada Gambar 2.c. menunjukkan adanya penurunan nilai absorbansi namun lebih rendah dibandingkan F-04. Hal tersebut berarti bahwa penginjeksian doping maksimum terjadi pada injeksi dengan waktu 90 menit.

Berikut penurunan nilai absorbansi pada setiap sampel terhadap waktu penyinaran dalam bentuk grafik dapat dilihat pada Gambar 3.

Gambar 3. Nilai absorbasi terkecil dengan penurunan absorbansi terbesar diperoleh pada sampel F-04. Hal ini dapat dilihat dari nilai absorbansi pada waktu penyinaran 50 menit, yakni sebesar 0 . Nilai ini merupakan nilai absorbansi terkecil dari semua sampel yang ada. Rendahnya nilai absorbansi mengindikasikan bahwa konsentrasi larutan remazol kuning berkurang karena adanya aktivitas fotokatalisis yang tinggi dari sampel F-04.

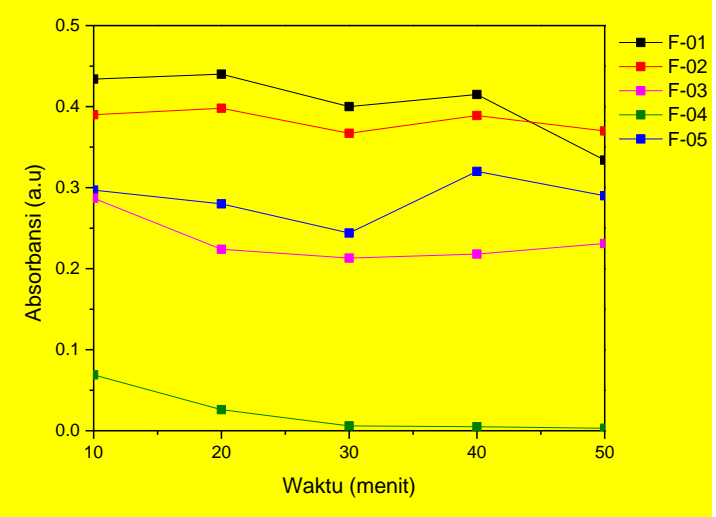

Gambar 3. Hasil pendegradasian remazol kuning.

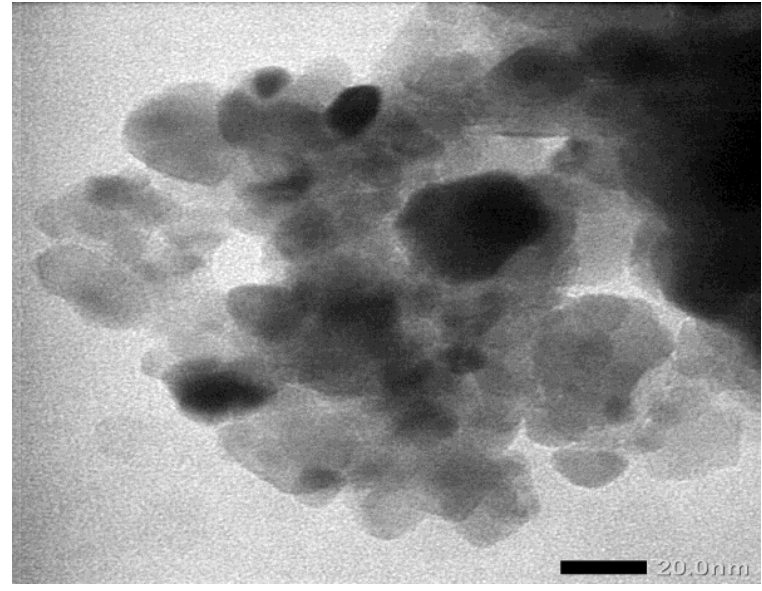

Gambar 4. Hasil analisis TEM pada sampel F-04

Hasil analisis TEM yang ditampilkan pada Gambar 4, menunjukkan bahwa nanostruktur sampel laju injeksi doping fluor 90 menit. Terlihat tidak adanya proses adhesi pada sampel tersebut. Proses adhesi tersebut diradiasi dengan neutron, sehingga dapat mempengaruhi sifat elektrofisika bahan nano tersebut. Butiran yang dihasilkan berbentuk bulat, padat dan saling bersentuhan (close packed particles). Selain itu, terdapat bagian tertentu yang terang dan bagian yang gelap. Hal tersebut dikarenakan ketika elektron datang kemudian ditransmisikan melalui cuplikan tanpa terjadi interaksi didalam cuplikan, maka transmisi elektron akan berbanding terbalik dengan ketebalan sampel. Daerah cuplikan lebih tebal akan mentransmisikan elektron lebih sedikit sehingga citra terlihat lebih gelap. Sebaliknya, bila daerah cuplikan lebih tipis maka gambar TEM terlihat lebih terang. Setelah dilakukan identifikasi ukuran partikel dengan menggunakan perangkat lunak imageJ menunjukkan bahwa ukuran partikel rata-rata pada nanotitania adalah (14 $\pm 4) \mathrm{nm}$. Adapun dampak dari penetesan doping yang semakin lama, maka dapat memberikan kesempatan bahan untuk bereaksi. Sesuai dengan metode yang digunakan yaitu metode sol gel, bahwa semakin lambat laju pengendapan prekursor maka semakin kecil dan homogen butiran 
yang diperoleh dari suatu bahan tersebut [20].

\section{KESIMPULAN}

Berdasarkan penelitian yang telah dilakukan maka dapat ditarik kesimpulan bahwa aktivitas fotokatalis maksimum terjadi pada panjang gelombang $410 \mathrm{~nm}$ ketika disinari dibawah lampu UV. Aktivitas fotokatalis terbaik terdapat pada sampel dengan injeksi $0.3 \mathrm{ml} / \mathrm{jam}$ dengan nilai absorbansi mencapai nol, dan ukuran butiran $\mathrm{F}_{-} \mathrm{TiO}_{2}$ berdasarkan hasil uji karakterisasi TEM dengan menggunakan software ImageJ adalah $14 \mathrm{~nm}$.

\section{UCAPAN TERIMAKASIH}

Terima kasih kepada Kepala Laboratorium Optik Jurusan Fisika serta Kepala Laboratorium Kimia Fisik dan Anorganik Jurusan Kimia FMIPA Universitas Lampung yang telah memfasilitasi laboratorium.

\section{DAFTAR PUSTAKA}

[1] J. Yang and S. Tighe, "A Review of Advances of Nanotechnology in Asphalt Mixtures," Procedia - Soc. Behav. Sci., vol. 96, no. Cictp, pp. 1269-1276, 2013.

[2] J. Parameswaranpillai, N. Hameed, T. Kurian, and $\mathrm{Y}$. Yu, "Introduction to Nanomaterials and Nanocomposites," Nanocomposite Mater., pp. 1-4, 2016.

[3] G. Yang, Z. Yan, and T. Xiao, "Lowtemperature solvothermal synthesis of visible-light-responsive S-doped TiO 2 nanocrystal," Appl. Surf. Sci., vol. 258, no. 8, pp. 4016-4022, 2012.

[4] S. T. Hayle and G. G. Gonfa, "Synthesis and characterization of titanium oxide nanomaterials using sol-gel method," vol. 2, no. 1, pp. 1-
7, 2014.

[5] K. Thamaphat, P. Limsuwan, and B. Ngotawornchai, "Phase Characterization of TiO 2 Powder by XRD and TEM," Kasetsart J. (Nat. Sci.), vol. 42, pp. 357-361, 2008.

[6] K. Nishizawa, M. Okada, and E. Watanabe, "New Preparation Method of Visible Light Responsive Titanium Dioxide Photocatalytic Films," Mater. Sci. Appl., vol. 05, no. 03, pp. 112-123, 2014.

[7] R. K. Wahi et al., "Photodegradation of Congo Red catalyzed by nanosized TiO2," J. Mol. Catal. A Chem., vol. 242, no. 1-2, pp. 48-56, 2005.

[8] N. N. Binitha, Z. Yaakob, and R. Resmi, "Influence of synthesis methods on zirconium doped titania photocatalysts," Cent. Eur. J. Chem., vol. 8, no. 1, pp. 182-187, 2010.

[9] S. J. Darzi, A. R. Mahjoub, and S. Sarfi, "Visible-light-active nitrogen doped tio2 nanoparticles prepared by sol-gel acid catalyzed reaction," Iran. J. Mater. Sci. Eng., vol. 9, no. 3, pp. 17-23, 2012.

[10] K. Palanivelu, J.-S. Im, and Y.-S. Lee, "Carbon Doping of TiO 2 for Visible Light Photo Catalysis - A review ," Carbon Lett., vol. 8, no. 3, pp. 214224, 2007.

[11] T. Ohno, T. Mitsui, and $M$. Matsumura, "Photocatalytic Activity of S-doped $\mathrm{TiO}_{2}$ Photocatalyst under Visible Light," Chem. Lett., vol. 32, no. 4, pp. 364-365, 2003.

[12] E. Fakhrutdinova, A. V. Shabalina, and E. Sudareva, "Synthesis of $\mathrm{TiO}_{2}$ and F-Doping $\mathrm{TiO}_{2}$ Powders via 'Reverse' Hydrolysis of Titanium Tetraisopropoxide," Adv. Mater. Res., vol. 1085, pp. 95-100, 2015.

[13] Y. Hendrix, A. Lazaro, Q. L. Yu, and H. J. H. Brouwers, "Influence of synthesis conditions on the properties of photocatalytic titania-silica 
composites," J. Photochem. Photobiol. A Chem., vol. 371, no. June 2018, pp. 25-32, 2019.

[14] M. YusoffM.S., M. Em., M. M, and W. Paulus, "Effect On Used Of Different $\mathrm{HCl}$ Molarities to the Characteristic of Nanotitania Powder Produced Via the Hydrothermal Method," APCBEE Procedia, vol. 3, no. May, pp. 250-254, 2012.

[15] O. Carp, C. L. Huisman, and A. Reller, "Photoinduced reactivity of titanium dioxide," Prog. Solid State Chem., vol. 32, no. 1-2, pp. 33-177, 2004.

[16] W. Yu et al., "Enhanced visible light photocatalytic degradation of methylene blueby F-doped TiO 2," Appl. Surf. Sci., vol. 319, no. 1, pp. 107-112, 2014.

[17] F. M. M. Sol-gel and L. M. Sari, "No Title," 2017.

[18] J. C. Yu, J. Yu, W. Ho, Z. Jiang, and L. Zhang, "Effects of F- doping on the photocatalytic activity and microstructures of nanocrystalline TiO2 powders," Chem. Mater., vol. 14, no. 9, pp. 3808-3816, 2002.

[19] U.

Diebold, " $<$ (Surf.Sci.Rep.)[2003]The surface science of titanium dioxide.pdf $>$," vol. 48, no. x, 2002.

[20] C. Su, B. Y. Hong, and C. M. Tseng, "Sol-gel preparation and photocatalysis of titanium dioxide," Catal. Today, vol. 96, no. 3, pp. 119 126, 2004.

[1] J. Yang and S. Tighe, "A Review of Advances of Nanotechnology in Asphalt Mixtures," Procedia - Soc. Behav. Sci., vol. 96, no. Cictp, pp. 1269-1276, 2013.

[2] J. Parameswaranpillai, N. Hameed, T. Kurian, and $\mathrm{Y} . \mathrm{Yu}$, "Introduction to Nanomaterials and Nanocomposites," Nanocomposite Mater., pp. 1-4,
2016.

[3] G. Yang, Z. Yan, and T. Xiao, "Lowtemperature solvothermal synthesis of visible-light-responsive S-doped TiO 2 nanocrystal," Appl. Surf. Sci., vol. 258, no. 8, pp. 4016-4022, 2012.

[4] S. T. Hayle and G. G. Gonfa, "Synthesis and characterization of titanium oxide nanomaterials using sol-gel method," vol. 2, no. 1, pp. 17, 2014.

[5] K. Thamaphat, P. Limsuwan, and B. Ngotawornchai, "Phase Characterization of TiO 2 Powder by XRD and TEM," Kasetsart J. (Nat. Sci.), vol. 42, pp. 357-361, 2008.

[6] K. Nishizawa, M. Okada, and E. Watanabe, "New Preparation Method of Visible Light Responsive Titanium Dioxide Photocatalytic Films," Mater. Sci. Appl., vol. 05, no. 03, pp. 112-123, 2014.

[7] R. K. Wahi et al., "Photodegradation of Congo Red catalyzed by nanosized TiO2," J. Mol. Catal. A Chem., vol. 242, no. 1-2, pp. 48-56, 2005.

[8] N. N. Binitha, Z. Yaakob, and R. Resmi, "Influence of synthesis methods on zirconium doped titania photocatalysts," Cent. Eur. J. Chem., vol. 8, no. 1, pp. 182-187, 2010.

[9] S. J. Darzi, A. R. Mahjoub, and S. Sarfi, "Visible-light-active nitrogen doped tio2 nanoparticles prepared by sol-gel acid catalyzed reaction," Iran. J. Mater. Sci. Eng., vol. 9, no. 3, pp. 17-23, 2012.

[10] K. Palanivelu, J.-S. Im, and Y.-S. Lee, "Carbon Doping of TiO 2 for Visible Light Photo Catalysis - A review ," Carbon Lett., vol. 8, no. 3, pp. 214224, 2007.

[11] T. Ohno, T. Mitsui, and $M$. Matsumura, "Photocatalytic Activity of S-doped $\mathrm{TiO}_{2}$ Photocatalyst under Visible Light," Chem. Lett., vol. 32, 
no. 4, pp. 364-365, 2003.

[12] E. Fakhrutdinova, A. V. Shabalina, and E. Sudareva, "Synthesis of $\mathrm{TiO}_{2}$ and F-Doping $\mathrm{TiO}_{2}$ Powders via 'Reverse' Hydrolysis of Titanium Tetraisopropoxide," Adv. Mater. Res., vol. 1085, pp. 95-100, 2015.

[13] Y. Hendrix, A. Lazaro, Q. L. Yu, and H. J. H. Brouwers, "Influence of synthesis conditions on the properties of photocatalytic titania-silica composites," J. Photochem. Photobiol. A Chem., vol. 371, no. June 2018, pp. 25-32, 2019.

[14] M. YusoffM.S., M. Em., M. M, and W. Paulus, "Effect On Used Of Different $\mathrm{HCl}$ Molarities to the Characteristic of Nanotitania Powder Produced Via the Hydrothermal Method," APCBEE Procedia, vol. 3, no. May, pp. 250-254, 2012.

[15] O. Carp, C. L. Huisman, and A. Reller, "Photoinduced reactivity of titanium dioxide," Prog. Solid State Chem., vol. 32, no. 1-2, pp. 33-177, 2004.

16] W. Yu et al., "Enhanced visible light photocatalytic degradation of methylene blueby F-doped TiO 2," Appl. Surf. Sci., vol. 319, no. 1, pp. 107-112, 2014.
[17] L. Sari, Megadia, "Sintesis dan Karakterisasi Nanotitania yang Didoping Fluor Menggunakan Metode Sol Gel," Thesis.2017.

[18] J. C. Yu, J. Yu, W. Ho, Z. Jiang, and L. Zhang, "Effects of F- doping on the photocatalytic activity and microstructures of nanocrystalline TiO2 powders," Chem. Mater., vol. 14, no. 9, pp. 3808-3816, 2002.

[19] U.Diebold, "“ $<$ (Surf.Sci.Rep.)[2003]The surface science of titanium dioxide.pdf $>$," vol. 48, no. x, 2002.

[20] C. Su, B Y. Hong, and C. M. Tseng, "Sol-gel preparation and photocatalysis of titanium dioxide," Catal. Today, vol. 96, no. 3, pp. 119126, 2004. 
Sri Rahayu, dkk: Pengaruh Laju Penginjeksian Doping Fluor terhadap Aktivitas Fotokatalis Nanotitania Menggunakan Metode Sol Gel 